\title{
Anti-Brucella abortus antibodies in free-ranging equids from Mossoró, Rio Grande do Norte, Brazil
}

\section{Anticorpos anti-Brucella abortus em equídeos errantes do município de Mossoró, Rio Grande do Norte}

\author{
Elaine Maria Seles Dorneles ${ }^{1}$; Leíse Gomes Fernandes²; \\ Jordana Almeida Santana ${ }^{3}$; Francisco Joelson Correa Freitas ${ }^{4}$; \\ Joseney Maia de Lima4; Isabella de Oliveira Barros; \\ Sidnei Miyoshi Sakamoto5; Marcos Bryan Heinemann ${ }^{6}$; Andrey Pereira Lage ${ }^{7 *}$
}

\begin{abstract}
The aims of the present study were (i) to determine the occurrence and (ii) to evaluate possible factors associated with infection by Brucella abortus in free-ranging equids from Mossoró, Rio Grande do Norte, Brazil. Sera from 227 free-ranging equids (178 donkeys, 43 horses and 6 mules), captured by the highway police and the prefecture agents, were screened by the rose bengal test (RBT) and confirmed for B. abortus-antibodies by the standard tube agglutination (STAT) and the 2-mercaptoethanol (2ME) tests. Of the 227 equids tested, four $(1.76 \%)$ were positive for $B$. abortus antibodies. All were horses, which resulted in an observed frequency of infection for this species of $9.30 \%(4 / 43)$. No association was found among seropositivity for $B$. abortus and the age and sex. Thus, data from the present study showed that infection by $B$. abortus is present among horses in Mossoró, Rio Grande do Norte, Brazil. Key words: Brucellosis, B. abortus, free-ranging equids, Mossoró
\end{abstract}

\section{Resumo}

Os objetivos deste trabalho foram (i) determinar a ocorrência da infecção por Brucella abortus em equídeos de vida livre no município de Mossoró, Rio Grande do Norte e (ii) avaliar possíveis fatores associados a esta infecção. Soros de 227 equídeos (178 asininos, 43 equinos e 6 muares), capturados pela polícia rodoviária e funcionários da prefeitura, foram coletados por punção venosa. A pesquisa de anticorpos anti-Brucella abortus foi realizada empregando-se, como triagem, o teste do antígeno acidificado tamponado (AAT) e como confirmatório o teste de redução pelo 2-Mercaptoetanol (2ME). Dos animais testados, quatro $(1,76 \%)$ foram positivos para anticorpos anti- B. abortus. Todos os

\footnotetext{
${ }^{1}$ M.e. em Ciência Animal, Escola de Veterinária, Universidade Federal de Minas Gerais, UFMG, Av. Antônio Carlos 6627, 30123 970, Belo Horizonte, MG. E-mail: selesdorneles@yahoo.com.br

${ }^{2}$ M.e. em Ciência Animal Dept ${ }^{\circ}$ de Ciências Animais, Universidade Federal Rural do Semi Árido, UFERSA, Av. Francisco Mota, 572, 59625900, Mossoró, RN. E-mail: leisegf@hotmail.com; doutorabellaodb@hotmail.com

${ }_{3}^{3}$ M.e. em Ciência Animal, Escola de Veterinária, UFMG, Belo Horizonte, MG. E-mail: jordanaalmeidasantana@gmail.com

${ }^{4}$ Graduados em Medicina Veterinária, UFERSA, Mossoró, RN. E-mail: joseneylima@hotmail.com, joelsonfreitas88@hotmail. com

${ }^{5}$ Prof. Dr. em Epidemiologia Experimental Aplicada às Zoonoses, Dept ${ }^{\circ}$ de Ciências Animais, UFERSA, Mossoró, RN. E-mail: sakamoto@ufersa.edu.br

${ }^{6}$ Prof. Dr. em Epidemiologia Experimental Aplicada às Zoonoses, Escola de Veterinária, UFMG, Belo Horizonte, MG. E-mail: mabryan@vet.ufmg.br

${ }^{7}$ Prof. Dr. em Bacteriologia, Escola de Veterinária, UFMG, Belo Horizonte, MG. E-mail: aplage@vet.ufmg.br

* Author for correspondence
} 
positivos eram equinos $(9,30 \%, 4 / 43)$. A análise das variáveis levantadas (sexo e idade) como possíveis fatores associados à infecção por $B$. abortus não revelou a existência de associação entre estas e a soropositividade. Assim, o presente estudo permite concluir que a infecção por B. abortus está presente em equinos do município de Mossoró, Rio Grande do Norte.

Palavras-chave: Brucelose, B. abortus, equídeos errantes, Mossoró

Brucella abortus infection in horses was a wellstudied subject during the 1970s and 1980s but recently, only a few reports could be found in the literature. Brucellosis in equids is important due to its clinical manifestations, which could result in the reduction of working capacity. Moreover, infected equids could be a potential source of infection to other species, including man (DENNY 1973). The frequencies of Brucella spp. infection in equids observed in studies throughout the world vary from $0.0 \%$ to $73.1 \%$ in horses, $0.0 \%$ to $7.4 \%$ in donkeys and $0.0 \%$ to $0.95 \%$ in mules (HIPÓLITO; SOUZA; GIÓVINE, 1943; HUTCHINS; LEPHERD, 1968; VIANA; REIS; SANTOS, 1981; LANGONI; SILVA, 1997; OMER et al., 2000; SILVA et al., 2001; REFAI, 2002; RIBEIRO et al., 2003; MUSA, 2004; OCHOLI et al., 2004; CVETNIC et al., 2005; ACOSTA-GONZÁLEZ; GONZÁLES-REYES; FLORES-GUTIÉRREZ, 2006; AGUIAR et al., 2008; ABO-SHEHADA, 2009; ARAÚJO et al., 2009; JUNQUEIRA JUNIOR, 2012). The most frequent clinical manifestations of brucellosis in equids are lesions of articular surfaces and synovial membranes, as bursitis, synovitis, osteoarthritis and osteomyelitis (LANGENEGGER; SZECHY, 1961; COLLINS et al., 1971; DENNY 1973). Reproductive problems are less frequent, although abortion has already been reported in mares and donkeys (CROSSMAN; BONSON, 1968; ROBERTSON et al., 1973; HINTON; BARKER; MORGAN, 1977).

In Brazil, the epidemiological situation of brucellosis in horses, and especially in donkeys and mules is poorly known, due to the scarcity of research focusing this disease (LANGENEGGER; SZECHY, 1961; GODOY; BARG, 1976; VIANA; REIS; SANTOS, 1981; LANGONI; SILVA, 1997;
RIBEIRO et al., 2003, JUNQUEIRA JUNIOR, 2012). B. abortus is the most commonly agent associated with brucellosis in equines, and horses usually get infected when raised in close contact with infected cattle (MCNUTT; MURRAY, 1924; CARPENTER; BOAK, 1937; STONE, 1938; FITCH; DODGE, 1939; MACMILLAN, 1985). The isolation and identification of Brucella spp. provide the conclusive diagnosis of brucellosis in horses, however, due to biosafety and technical issues associated with the culture of Brucella spp., serological tests, which shows good correlation with the infection status, were widely used for the identification of infected animals (DENNY, 1972).

Considering the zoonotic aspects of brucellosis, losses from the infection for breeders and the lack of information on the epidemiology of brucellosis in equids, the aims of this study were (i) to determine the occurrence and (ii) to evaluate possible factors associated with $B$. abortus infection in free-ranging equids from the municipality of Mossoró, Rio Grande do Norte, Brazil.

The survey was conducted between August 2009 and March 2010, in the municipality of Mossoró, Rio Grande do Norte, Brazil. All free-ranging equids captured by the highway police and the agents of the prefecture of Mossoró in the period were included in the study. Blood of 227 equids - 178 donkeys, 43 horses and 6 mules-, were collected by venipuncture and serum was separated and stored at $-20^{\circ} \mathrm{C}$ until the time of analysis. The gender and age of each animal were recorded. The age of animals was estimated by modification in the occlusal face, the eruption of the teeth and by the continued erosion of its constituents (SILVA et al., 2003).

Sera were screened by the rose bengal test (RBT) (Instituto de Tecnologia do Paraná - TECPAR, 
Brazil) and confirmed for $B$. abortus-antibodies by the standard tube agglutination (STAT) and the 2-mercaptoethanol (2ME) tests (TECPAR, Brazil) (ALTON et al., 1988; BRASIL, 2006). Animals presenting serological titers greater than or equal to 50 in STAT were considered positive (DENNY, 1973). Prevalence and confidence intervals were calculated by the function binCI of the package binGroup (ZHANG et al., 2011) using the R software, version 2.14.1 (R DEVELOPMENT CORE TEAM, 2011). Association of seropositivity and gender or age was studied by the chi-square and Fisher exact test, using an $\alpha$ error of 0.05 (SAMPAIO, 2002). Factors associated to infection were analysed using the software Epi-Info 6.4 (DEAN et al., 1995). This experimental protocol was approved by the Ethics
Committee in Animal Experimentation of the Universidade Federal de Minas Gerais (CETEAUFMG, Protocol 182/10).

Of the 227 equids tested, four $(1.76 \%, 95 \%$ Confidence Interval (CI): $0.48 \%$ to $4.45 \%$ ) were positive for antibodies anti-B abortus. No donkeys $(0 \%, 95 \%$ CI: $0 \% ; 2.05 \%)$ nor mules $(0 \%, 95 \%$ CI: $0 \% ; 45.93 \%)$ showed positive results. All four positive animals were horses; the frequency of positive animals among horses was $9.30 \%(95 \% \mathrm{CI}$ : $2.59 \% ; 22.14 \%)(4 / 43)$. The titers shown by positive horses for STAT and 2ME were, respectively, 100 and 50, 100 and negative, 100 and negative, and 50 and negative. No association was found between gender or age and seropositivity for B. abortus. The results are summarized in Table 1.

Table 1. Number of equids positive and negative to B. abortus infection according to the possible factors associated with brucellosis.

\begin{tabular}{|c|c|c|c|}
\hline Factors associated & Positive & Negative & $\mathbf{P}^{1}$ \\
\hline Sex & & & 0.339 \\
\hline Male & $1 / 21$ & $20 / 21$ & \\
\hline Female & $3 / 22$ & $19 / 22$ & \\
\hline Age & & & 0.825 \\
\hline Up to 2 years & $0 / 1$ & $1 / 1$ & \\
\hline 3 to 5 years & $0 / 5$ & $5 / 5$ & \\
\hline 6 to 8 years & $3 / 27$ & $25 / 27$ & \\
\hline 9 to 11 years & $1 / 6$ & $5 / 6$ & \\
\hline Above 12 years & $0 / 4$ & $4 / 4$ & \\
\hline
\end{tabular}

${ }^{1}$ probability of random occurrence $(\mathrm{P})$ in the univariate analysis.

Source: Elaboration of the authors

The presence of seropositive horses in the equine population of the Mossoró suggests that these animals were in contact with $B$. abortus, since the diagnostic tests employed have good correlation with the infection (MACMILLAN et al., 1982). Cattle are the main host of B. abortus (CORBEL; ELBERG; COSIVI, 2006), and although the mechanism of transmission of brucellosis to horses is unclear, it is considered to be favored by cohabitation between these two domestic species (DENNY, 1972). In most cases, horses infected with $B$. abortus have great contact with cattle (DENNY, 1973). It is also worth considering that, after being captured, the animals were confined, transferred to another location, and, then released again. Thus, animals with different health status are grouped together for a short period and then released, enlarging the risk of transmission of B. abortus among the animals.

Bovine brucellosis is endemic throughout Brazil (POESTER; GONÇALVES; LAGE, 2002) and serological surveys conducted in cattle in some 
States of the Northeastern Region have confirmed the presence of seropositive herds and animals in the region (ALVES et al., 2009; SILVA et al., 2009). Although data on the situation of brucellosis in the State of Rio Grande do Norte is scarce, the occurrence of positive horses observed in this study may reflect the presence of infection in cattle population of the state.

A direct comparison among the frequencies of the positive animals (horses, mules and donkeys) found in serological surveys conducted in Brazil and in different countries and the results obtained in the present study is difficult, mainly due to differences in experimental designs, serological assays, diagnostic cutoff points, and size and representativeness of the sampling. Although donkeys and mules show a similar infection course as that observed on horses (LANGENEGGER; SZECHY, 1961; CROSSMAN, BONSON, 1968; PORTUGAL et al., 1971; ENRIGHT, 1990), it is hard to assess the real impact of Brucella spp. infection on these species or their importance in the epidemiology of brucellosis. The assessment of the situation of brucellosis in donkeys and mules is of particular importance in the Northeastern region, since this is the Brazilian region which concentrates the largest population of these two species (IBGE, 2006). The absence of seropositive animals among donkeys and mules in the present study suggests that the infection is not present or the prevalence is too low in their population in Mossoró. Moreover, in the case of mules, the number of animals captured was probably too small to assess the prevalence, as suggests the large confidence interval of the prevalence.

In conclusion, the present study indicates that infection with $B$. abortus is present in free-range horses of the municipality of Mossoró, Rio Grande do Norte, Brazil.

\section{Acknowledgements}

This study was supported by Conselho Nacional de Desenvolvimento Técnico e Científico - CNPq, Fundação de Amparo à Pesquisa do Estado de Minas Gerais - FAPEMIG, Fundação de Ensino e Pesquisa em Medicina Veterinária e Zootecnia - FEP-MVZ Coordenação Preventiva and Coordenação de Aperfeiçoamento do Pessoal de Nível Superior - Capes (Procad Novas Fronteiras EV-UFSA). EMSD, JAS, MBH and APL have fellowships from the CNPq.

\section{References}

ABO-SHEHADA, M. N. Seroprevalence of Brucella species in equids in Jordan. Veterinary Record, London, v. 165, n. 9, p. 267-268, 2009.

ACOSTA-GONZÁLEZ, R. I.; GONZÁLEZ-REYES, I.; FLORES-GUTIÉRREZ, G. H. Prevalence of Brucella abortus antibodies in equines of a tropical region of Mexico. Canadian Journal Veterinary Research, Ontario, v. 70, n. 4, p. 302-304, 2006.

AGUIAR, D. M.; CAVALCANTE, G. T.; LARA, M. C. C. S. H.; VIllalobos, E. M. C.; CUNHA, E. M. S.; OKUDA, L. I.; ESTÉFANO, E.; NASSAR, A. F. C.; SOUZA, G. O.; VASCONCELlOS, S. A.; LABRUNA, M. B.; CAMARGO, L. M. A.; GENNARI, S. M. Prevalência de anticorpos contra agentes virais e bacterianos em equídeos do município de Monte Negro, Rondônia, Amazônia Ocidental Brasileira. Brazilian Journal of Veterinary Research and Animal Science, São Paulo, v. 45, n. 4, p. 269-276, 2008.

ALTON, G. G.; JONES, L. M.; ANGUS, R. D.; VERGER, J. M. Techniques for the Brucellosis laboratory. Paris: Institut National de La Recherche Agronomique, 1988, $190 \mathrm{p}$.

ALVES, A. J. S.; GONÇALVES, V. S. P.; FIGUEIREDO, V. C. F.; LÔBO, J. R.; BAHIENSE, L.; AMAKU, M.; FERREIRA, F.; FERREIRA NETO, J. S.; DIAS, R. A. Situação epidemiológica da brucelose bovina no Estado da Bahia. Arquivo Brasileiro de Medicina Veterinária e Zootecnia, Belo Horizonte, v. 61, p. 6-13, 2009. Suplemento 1. 
ARAÚJO, R. R.; PENA, L. J.; PENA, D. A.; DIAS, F. M.; MORAES, M. P. Ocorrência de anticorpos antiBrucella spp. em equídeos da região da zona da mata do estado de Minas Gerais, Brasil. Arquivos do Instituto Biológico, São Paulo, v. 76, n. 4, p. 681-684, 2009.

BRASIL. Manual técnico do programa nacional de controle e erradicação da brucelose e da tuberculose PNCEBT. Brasília: Ministério da Agricultura, Pecuária e Abastecimento, Programa Nacional de Controle e Erradicação da Brucelose e Tuberculose MAPA/DSA/ DAS, 2006, 184 p.

CARPENTER, C. M.; BOAK, R. A. The significance of the horse in Brucellosis. Journal of Bacteriology, Washington, v. 33, n. 1, p. 40, 1937.

COLLINS, J. D.; KELLY, W. R.; TWOMEY, T.; FARRELLY, B. T.; WHITTY, B. T. Brucella-associated vertebral osteomyelitis in a thoroughbred Mare. Veterinary Record, London, v. 88, n. 13, p. 321-326, 1971.

CORBEL, M. J.; ELBERG, S. S.; COSIVI, O. Brucellosis in humans and animals. Geneva: World Health Organization, 2006. 89 p.

CROSSMAN, P. J.; BONSON, M. D. Abortion in a Donkey associated with Brucella abortus. Veterinary Record, London, v. 82, n. 22, p. 607-608, 1968.

CVETNIC, Z.; SPICIC, S.; CURIC, S.; JUKIC, B.; LOJKIC, M.; ALBERT, D.; THIÉBAUD, M.; GARINBASTUJI, B. Isolation of Brucella suis biovar 3 from horses in Croatia. Veterinary Record, London, v. 156, n. 19, p. 584-585, 2005.

DEAN, A. G.; DEAN, J. A.; BURTON, A. H.; DICKER, R. C. EPI INFO, version 6.02b: a word processing, database and statistics program for epidemiology on micro-computers. Atlanta: Center for Disease Control, 1995.

DENNY, H. R. A review of brucellosis in the horse. Equine Veterinary Journal, Oxford, v. 5, n. 3, p. 121-125, 1973.

Brucellosis in the horse. Veterinary Record, London, v. 90, n. 4, p. 86-91, 1972.

ENRIGHT, F. M. The pathogenesis and pathobiology of Brucella infection in domestic. In: NIELSEN, K.; DUNCAN, J. R. (Ed.). Animal brucellosis. Boca Raton: CRC Press, 1990. p. 301-320.

FITCH, C. P.; DODGE, R. E. Horses as possible means of spread of Bang's disease among cattle. Cornell Veterinarian, Ithaca, v. 29, n. 10, p. 29-31, 1939.
GODOY, A. M.; BARG, L. Aspectos ecológicos da infecção brucélica 2 - investigação sorológica em cavalos de corrida. Arquivos da Escola de Veterinária da UFMG, Belo Horizonte, v. 28, n. 2, p. 121-123, 1976.

HINTON, M.; BARKER, G. L.; MORGAN, T. L. A. Abortion in a mare associated with Brucella abortus infection and twins. Veterinary Record, London, v. 101, n. 26-27, p. 526, 1977.

HIPÓLITO, O.; SOUZA, R.; GIÓVINE, N. Brucelose e sôro - aglutinação em Minas Gerais. Arquivos da Escola Superior de Veterinária, Belo Horizonte, v. 1, n. 1, p. 3134, 1943.

HUTCHINS, D. R.; LEPHERD, E. E. The occurrence of agglutinins to Brucella abortus in horses. Australian Veterinary Journal, Victoria, v. 44, n. 7, p. 323-325, 1968.

INSTITUTO BRASILEIRO DE GEOGRAFIA E ESTATÍSTICA - IBGE. Censo agropecuário 2006. Minas Gerais, 2006. Disponível em: <http://www.ibge. gov.br>. Acesso em: 11 nov. 2010.

JUNQUEIRA JUNIOR, D. G. Soroprevalência da brucelose em equídeos de serviço em Minas Gerais, 2003-2004. 2012. Dissertação (Mestrado em Ciência Animal) - Escola de Veterinária. Universidade Federal de Minas Gerais, Minas Gerais.

LANGENEGGER, J.; SZECHY, A. M. Brucelose dos equídeos domésticos: isolamento de Brucella abortus de bursites de cernelha no Brasil. Arquivos do Instituto Biológico Animal, São Paulo, v. 4, p. 49-63, 1961.

LANGONI, H.; SILVA, A. V. Comportamento sorológico de aglutininas anti-Brucella em soro de equídeos. Revista Brasileira de Medicina Veterinária, Rio de Janeiro, v. 19, n. 2, p. 85-87, 1997.

MACMILLAN, A. P. A retrospective study of the serology of brucellosis in horses. Veterinary Record, London, v. 117, n. 24, p. 638-639, 1985.

MACMILLAN, A. P.; BASKERVILLE, A.; HAMBLETON, P.; CORBEL, M. J. Experimental Brucella abortus infection in the horse: observations during the three months following inoculation. Research in Veterinary Science, London, v. 33, n. 3, p. 351-359, 1982.

MCNUTT, S. H.; MURRAY, C. Bacterium abortion (Bang) isolated from the fetus of an aborting mare. Journal of the American Veterinary Medical Association, Chicago, v. 97, p. 576-580, 1924.

MUSA, M. T. A serological study on equine brucellosis in Darfur, Western Sudan. The Sudan Journal of Veterinary Research, King Abdul Aziz, v. 19, n. 2, p. 7-11, 2004. 
OCHOLI, R. A.; BERTU, W. J.; KWAGA, J. K. P.; AJOGI, I.; BALE, J. O.; OKPARA, J. Carpal bursitis associated with Brucella abortus in a horse in Nigeria. Veterinary Record, London, v. 155, n. 18, p. 566-567, 2004.

OMER, M. K.; SKEJERVE, E.; HOLSTAD, G.; WOLDEHIWET, Z.; MACMILLAN, A. P. Prevalence of antibodies to Brucella spp. in cattle, sheep, goats, horses and camels in the State of Eritrea; influence of husbandry systems. Epidemiology and Infection, Cambridge, v. 125, n. 2, p. 447-453, 2000.

POESTER, P. F.; GONÇALVES, P. S. V.; LAGE, A. P. Brucellosis in Brazil. Veterinary Microbiology, Amesterdan, v. 90, n. 1-4, p. 55-62, 2002.

PORTUGAL, M. A. S. C.; WESTI, A.; GIORGI, W.; FRANÇA, E. N.; OLIVEIRA JUNIOR, B. S. Brucelose em equídeos determinada por Brucella suis. Arquivos do Instituto Biológico, São Paulo, v. 38, p. 125-132, 1971. Suplemento 1.

R DEVELOPMENT CORE TEAM. A language and environment for statistical computing. R Foundation for Statistical Computing. Áustria. 2011. Disponível em: $<$ http://www.R-project.org>. Acesso em: 11 nov. 2010.

REFAI, M. Incidence and control of brucellosis in the Near East region. Veterinary Microbiology, Amesterdan, v. 90, n. 1-4, p. 81-110, 2002.

RIBEIRO, M. G.; NARDI JÚNIOR, G.; MEGID, J.; PAES, A. C.; LISTONI, F. J. P. Aglutininas anti-Brucella abortus no soro e em secreção de bursite cervical em eqüinos. Arquivo Brasileiro de Medicina Veterinária e Zootecnia, Belo Horizonte, v. 55, n. 1, p. 99-101, 2003.

ROBERTSON, F. J.; MILNE, J.; SILVER, C. L.; CLARK, H. Abortion associated with Brucella abortus (biotype 1) in mare. Veterinary Record, London, v. 92, n. 3, p. 480-481, 1973.
SAMPAIO, I. B. M. Estatística aplicada à experimentação animal. Belo Horizonte: Fundação de Ensino e Pesquisa em Medicina Veterinária e Zootecnia, 2002. 265 p.

SILVA, L. A. F.; ACYPRESTE, C. S.; EURIDES, D.; MACHADO, G. V.; DIAS FILHO, F. C.; FIORAVANTI, M. C. S.; RAMOS, L. S. Soroprevalência de brucelose em equinos com bursite cervical. Arquivos de Ciências Veterinárias e Zoologia da UNIPAR, Umuarama, v. 4, n. 1, p. 19-23, 2001.

SILVA, M. F.; GOMES, T.; DIAS, A. S.; MARQUES, J. S.; JORGE, L. M.; FAÍSCA, J. C.; PIRES, G. A.; CALDEIRA, R. M. Estimativa da idade dos equinos através do exame dentário. Revista Portuguesa de Ciências Veterinárias, Lisboa, v. 98, n. 547, p. 103-110, 2003.

SILVA, V. G. S. O.; DIAS, R.A.; FERREIRA, F.; AMAKU, M.; COSTA, E. L. S.; LÔBO, J. R.; GONÇALVES, V. C. F.; FERREIRA NETO, J. S. Situação epidemiológica da brucelose bovina no Estado de Sergipe. Arquivo Brasileiro de Medicina Veterinária e Zootecnia, Belo Horizonte, v. 61, p. 109-117, 2009. Suplemento 1.

STONE, W. S. Brucellosis in horses. Cornell Veterinarian, Ithaca, v. 28, n. 2, p. 91-98, 1938.

VIANA, F. C.; REIS, R.; SANTOS, W. L. M. Inquérito sorológico para brucelose eqüina em Minas Gerais. Arquivos da Escola de Veterinária da UFMG, Belo Horizonte, v. 33, n. 3, p. 431-435, 1981.

ZHANG, B.; BILDER, C.; BIGGERSTAFF, B.; SCHAARSCHMIDT, F. BinGroup: evaluation and experimental design for binomial group testing $2011 \mathrm{R}$ package version 1.0-9, 2011. Disponível em: <http:// CRAN.R-project.org/package=binGroup $>$. Acesso em: 11 nov. 2010. 